\title{
ANALISIS EFEKTIVITAS PENERIMAAN DAN KONTRIBUSI PAJAK HOTEL TERHADAP PENDAPATAN ASLI DAERAH KOTA TOMOHON (PADA BADAN KEUANGAN DAERAH KOTA TOMOHON)
}

\author{
Maya Rabunusa $^{1}$, Grace B. Nangoi ${ }^{2}$, I Gede Suwetja ${ }^{3}$ \\ 1,2,3 Jurusan Akuntansi, Fakultas Ekonomi dan Bisnis, Universitas Sam Ratulangi, Jl. Kampus Bahu, Manado, 95115, \\ Indonesia \\ E-mail : mayarabunusa@yahoo.com
}

\begin{abstract}
Regional Tax is a compulsory contribution to the region owed by an individual or a coercive body under applicable law by not receiving direct remuneration and being used for regional purposes for the greatest welfare of the people. The purpose of this research is to know the effectiveness and contribution of hotel tax to Locally Generated Revenue in Tomohon City. In this study used the type of qualitative and quantitative data, for data sources using secondary data and analytical methods used are kualitative descriptive. Based on the research results, it is concluded that the level of hotel tax effectiveness of 2012 - 2016 is very effective. The year 2016 is the highest hotel tax effectiveness rate of 134.01\%, while the lowest level of hotel tax effectiveness is in 2014 with a percentage of 27.40. Hotel tax contribution to Tomohon Locally Generated Revenue in 2012 - 2016 is good from year to year there is an increase although there is also a decrease. 2016 is the highest contribution of Hotel Tax to Locally Generated Revenue with percentage of $67.23 \%$ and the lowest is in 2015 with a percentage of $4.85 \%$ with an average contribution of $26,68 \%$.
\end{abstract}

Keywords: Effectiveness, Contributions, Hotel Tax, Local Revenue.

\section{PENDAHULUAN}

Pemerintah Daerah diberi kewenangan yang luas untuk mengurus rumah tangganya sendiri dengan sedikit mungkin campur tangan pemerintah pusat. Pemerintah daerah mempunyai hak dan kewenangan yang luas untuk menggunakan sumber-sumber ekonomi dan keuangan yang dimiliki oleh daerahnya. Hal ini selaras dengan UU No. 32 tahun 2004 tentang Pemerintahan Daerah dan UU No. 33 tahun 2004 tentang Perimbangan Keuangan antara Pemerintah Pusat dan Daerah. Tapi pada kenyataannya kontribusi Pendapatan Asli Daerah terhadap pendapatan dan belanja daerah masih kecil. Selama ini dominasi sumbangan pemerintah pusat kepada daerah masih besar. Untuk mengurangi dominasi sumbangan pemerintah pusat serta meningkatkan pembangunan dan memaksimalkan otonomi daerah, Pemerintah Daerah harus lebih meningkatkan Pendapatan Asli Daerah (PAD). Menurut UU No. 33 tahun 2004, PAD terdiri dari: (1) Hasil pajak daerah, (2) Hasil retribusi daerah, (3) Hasil perusahaan milik daerah dan hasil pengelolaan kekayaan daerah yang dipisahkan, dan (4) Pendapatan asli daerah yang lainnya. PAD menjadi indikator keberhasilan dalam penyelenggaraan otonomi daerah.

Semakin tinggi PAD maka semakin tinggi pula kemampuan pemerintah daerah untuk membiayai kebutuhannya sendiri. Hal ini berarti pemerintah daerah tersebut telah berhasil dalam menyelenggarakan otonomi daerah. Demikian pula sebaliknya, apabila PAD yang diperoleh pada daerah tersebut semakin sedikit atau mengalami penurunan, berarti penyelenggaraan otonomi daerahnya belum maksimal. Mengingat kota Tomohon sebagai salah satu daerah dengan destinasi wisata yang banyak maka semakin hari semakin banyak dikunjungi oleh para wisatawan sudah tentu dituntut untuk menyediakan berbagai fasilitas 
seperti hotel, pengimapan, losmen, rumah makan, restoran, tempat SPA,pengelaran seni budaya, aneka hiburan dan fasilitas lain.

Adanya Undang-Undang Otonomi Daerah memberi peluang lebih banyak bagi daerah untuk menggali potensi sumber-sumber penerimaan daerah dibanding peraturan-peraturan sebelumnya yang lebih banyak memberikan keleluasaan pada pemerintah di atasnya. Karena satu hal yang tidak bisa dipungkiri bagaimana konsep otonomi daerah adalah tetap selalu berada dalam wadah Negara Kesatuan Republik Indonesia. Dengan berlangsungnya otonomi daerah serta diberlakukannya UU No. 32 Tahun 2004 dan UU No. 33 Tahun 2014 mendorong terjadinya desentralisasi fiskal yaitu bagaimana pemerintah mengelola dan melaksanakan wewenang dalam mengatur pengeluaran daerah mereka sendiri. Di samping itu hal terpenting lainnya adalah kemampuan daerah masing-masing dalam upaya peningkatan kualitas pendapatan asli daerah (PAD).

Pajak daerah merupakan salah satu sumber Pendapatan Asli Daerah yang dipungut dari masyarakat tanpa mendapatkan imbalan langsung. Hal ini sesuai dengan UU no. 28 Tahun 2009 tentang Pajak Daerah dan Retribusi Daerah yang mengungkapkan bahwa Pajak Daerah adalah iuran wajib yang dilakukan oleh orang pribadi atau badan kepada daerah tanpa imbalan langsung yang seimbang, yang dapat dipaksakan berdasarkan peraturan perundangundangan yang berlaku, yang digunakan untuk membiayai penyelenggaran daerah dan pembangunan daerah. Dengan menggali serta meningkatkan potensi pajak daerah yang ada di daerah tersebut, maka PAD nantinya dapat digunakan untuk pembangunan serta meningkatkan kesejahteraan rakyat.

Terdapat perbedaan cakupan pajak antara daerah provinsi dan daerah kabupaten/kota. Menurut UU no. 28 Tahun 2009 tentang Pajak Daerah dan Retribusi Daerah, Daerah Provinsi memiliki 5 jenis pajak daerah, yaitu : (1) Pajak Kendaraan Bermotor, (2) Bea Balik Nama Kendaraan Bermotor, (3) Pajak Atas Bahan Bakar Kendaraan Bermotor, (4) Pajak Air Permukaan, dan (5) Pajak Rokok. Sedangkan jenis pajak yang dipungut oleh daerah kabupaten/kota ada 7 jenis pajak, yaitu : (1) Pajak Hotel, (2) Pajak Restoran, (3) Pajak Hiburan, (4) Pajak Reklame, (5) Pajak Penerangan Jalan, (6) Pajak Mineral Bukan Logam dan Batuan, (7) Pajak Parkir, (8) Pajak Air Tanah, (9) Pajak Sarang Burung Walet, (10) Pajak Bumi dan Bangunan Pedesaan dan Perkotaan, (11) Bea Perolehan Hak Atas Tanah dan Bangunan. Dalam era otonomi daerah, Pendapatan Asli Daerah (PAD) menjadi indikator keberhasilan penyelenggaraan otonomi daerah. Semakin tinggi PAD maka semakin tinggi pula kemampuan pemerintah daerah untuk membiayai kebutuhannya sendiri. Hal berarti pula bahwa pemerintah daerah tersebut telah berhasil dalam menyelenggarakan otonomi daerah. Demikian pula sebaliknya, apabila PAD yang diperoleh pada daerah tersebut semakin sedikit atau mengalami penurunan, berarti penyelenggaraan otonomi daerahnya belum maksimal.

Undang Undang Nomor 25 Tahun 2004 tentang Sistem Perencanaan Pembangunan Nasional, Peraturan Pemerintah Nomor 8 Tahun 2008 tentang Tahapan, Tatacara Penyusunan, Pengendalian dan Evaluasi Pelaksanaan Rencana Pembangunan Daerah dan Peraturan Menteri Dalam Negeri Nomor 54 tahun 2010 tentang Pelaksanaan Peraturan Pemerintah Nomor 8 Tahun 2008, mengamanatkan bahwa ruang lingkup perencanaan pembangunan daerah meliputi tahapan tatacara penyusunan, pengendalian dan evaluasi pelaksanaan rencana pembangunan daerah, yang salah satunya mensyaratkan disusunnya Rencana Strategis (RENSTRA) Satuan Kerja Perangkat Daerah (SKPD).

Badan Keuangan Daerah Kota Tomohon pada Tahun 2016 bernama Dinas Pendapatan Pengelolaan Keuangan dan Barang Milik Daerah ( DPPKBMD ) mengacu pada Peraturan Daerah Kota Tomohon No 3 Tahun 2012 tentang perubahan kedua Perda Kota Tomohon no 4 tahun 2008 tentang organisasi dan tata kerja dinas daerah, namun Pada tahun 2016 telah ditetapkan Peraturan Daerah No. 6 Tahun 2016 Tentang Pembentukan Dan Susunan Perangkat Daerah Kota Tomohon yang telah menyesuaikan dengan amanat 
Peraturan Pemerintah No 18 Tahun 2016 Tentang Perangkat Daerah sebagai bentuk tindak lanjut dari Undang-Undang Nomor 23 Tahun 2014 Tentang Pemerintahan Daerah.

\section{TINJAUAN PUSTAKA}

\subsection{Konsep Akuntansi}

Akuntansi American Accounting Association (AAA) dalam Soemarso (2009:3), mendefinisikan akuntansi sebagai proses mengidentifikasikan, mengukur dan melaporkan informasi ekonomi, untuk memungkinkan adanya penilaian dan keputusan yang jelas dan tegas bagi mereka yang menggunakan informasi tersebut.

\subsection{Konsep Pajak}

\subsubsection{Pengertian Pajak}

Pajak adalah iuran rakyat kepada kas negara berdasarkan undang-undang (yang dapat dipaksakan) dengan tiada mendapat jasa timbal (kontraprestasi) yang dapat langsung ditunjukan dan yang digunakan untuk membayar pengeluaran umum.

\subsubsection{Pengelompokan Pajak}

Dalam Mardiasmo (2016:7-6) Pengelompokan Pajak terbagi sebagai berikut:

1. Menurut Golongannya

a. Pajak Langsung

b. Pajak tidak langsung

2. Menurut Sifatnya

a. Pajak Subjektif

b. Pajak Objektif

3. Menurut Lembaga Pemungutnya

a. Pajak Pusat terdiri atas Pajak Penghasilan, Pajak Pertambahan Nilai, dan Pajak Penjualan Atas Barang Mewah.

b. Pajak Daerah terbagi menjadi 2 yaitu:

a) Pajak Provinsi yaitu: Pajak Kendaraan Bermotor, Bea BAlik NAma Kendaraan Bermotor, Pajak Bahan Bakar Kendaraan Bermotor, Pajak Air Permukaan.

b) Pajak Kabupaten/Kota yaitu: Pajak Hotel, Pajak Restoran, Pajak Hiburan, Pajak Reklame, Pajak Parkir, Pajak Sarang Burung Walet, PBB perkotaan dan Pedesaan, Pajak Air Tanah, Pajak Batuan dan Bukan Logam, Pajak Penerangan Jalan, BPHTB.

\subsubsection{Tarif Pajak}

Ada 2 macam tarif pajak dalam Mardiasmo (2016:11-12):

1. Tarif Pajak Tunggal

a. Tarif sebanding/proporsional

b. Tarif Tetap

2. Tarif Tidak Tunggal

\subsubsection{Fungsi Pajak}
a. Tarif Progresif

1. Fungsi budgetair (pembiayaan)

2. Fungsi regulerend (mengatur)

\subsubsection{Syarat Pemungutan Pajak}

1. Pemungutan pajak harus adil (Syarat Keadilan)

2. Pemungutan Pajak harus berdasarkan undang-undang (Syarat Yuridis)

3. Tidak Menganggu Perekonomian (Syarat Ekonomis)

4. Pemungutan Pajak Harus Efisien (Syarat Finansial)

5. Sistem Pemungutan Pajak Harus Sederhana

6. Tata Cara Pemungutan Pajak 


\subsection{Konsep Pajak Hotel}

\subsubsection{Pengertian Pajak Hotel}

Pajak Hotel adalah pajak atas pelayanan yang disediakan oleh hotel. Hotel adalah fasilitas penyedia jasa penginapan/peristirahatan termasuk jasa terkait lainnya dengan dipungut bayaran, yang mencakup jasa motel, losmen, gubuk pariwisata, wisma pariwisata, pesanggrahan, rumah penginapan dan sejenisnya.

\subsubsection{Objek Pajak Hotel}

Objek Pajak Hotel adalah pelayanan yang disediakan oleh hotel.

\subsubsection{Subjek Pajak dan Wajib Pajak Hotel}

Subjek pajak adalah orang pribadi atau badan yang melakukan pembayaran kepada orang pribadi atau badan yang mengusahakan hotel. Yang menjadi wajib pajak adalah orang pribadi atau badan yang mengusahakan hotel.

\subsection{Konsep Pendapatan Asli Daerah}

\subsubsection{Pengertian Pendapatan Asli Daerah}

PAD adalah pendapatan yang diperoleh daerah yang dipungut berdasarkan Peraturan Daerah sesuai dengan peraturan perundang-undangan. Menurut Mardiasmo (2013).

\subsubsection{Sumber Pendapatan Asli Daerah}

a. Pajak Daerah

b. Retribusi Daerah

c. Hasil pengelolaan kekayaan daerah yang dipisahkan

d. PAD lain-lain yang sah

\subsection{Konsep Efektivitas dan Kontribusi}

\subsubsection{Konsep Efektivitas}

$$
\text { Efektifitas }=\frac{\text { Realisasi penerimaan pajak hotel }}{\text { Target penerimaan pajak hotel }} \times 100 \%
$$

\subsubsection{Konsep Kontribusi}

Rumus Kontribusi:

$$
\text { Kontribusi }=\frac{\text { Penerimaan pajak hotel }}{\text { Penerimaan pendapatan asli daerah }} \times 100 \%
$$

\section{METODE PENELITIAN}

\subsection{Jenis Penelitian, Jenis Data, dan Sumber Data}

\subsubsection{Jenis Penelitian}

Jenis penelitian ini menggunakan jenis penelitian kualitatif yaitu dengan mengumpulkan data - data, mengolah data dan menganalisis data berupa rincian penerimaan pendapatan daerah.

\subsubsection{Jenis Data}

Data kualitatif adalah data yang berbentuk kata-kata, bukan dalam bentuk angka.

Data kuantitatif adalah data yang berbentuk angka atau bilangan.

\subsubsection{Sumber Data}

Sumber data dibedakan menjadi 2 yaitu:

1. Data Primer

2. Data Sekunder

\subsection{Tempat dan Waktu Penelitian}

Penelitian ini mengambil data di Badan Keuangan Daerah Kota Tomohon Waktu penelitian dari bulan September 2017 sampai dengan selesai.

\subsection{Prosedur Penelitian}

1. Melakukan permohonan izin penelitian di Badan Keuangan Daerah Kota Tomohon. 
2. Melakukan wawancara dengan pihak terkait.

3. Mengumpulkan data yang diperlukan.

4. Melakukan proses olah data dan analisis data tentang efektivitas dan kontribusi Pajak Hotel.

5. Membuat hasil dan pembahasan penelitian.

6. Membuat kesimpulan dan saran.

\section{Hasil Penelitian}

\subsubsection{Data Penerimaan Pajak Hotel.}

Tabel 4.1

Target dan Realisasi Penerimaan Pajak Hotel Kota Tomohon Tahun 2012-2016

\begin{tabular}{cccc}
\hline Tahun & Target $(\mathbf{R p )}$ & Realisasi $(\mathbf{R p )}$ & Selisih $(\mathbf{R p )}$ \\
\hline $\mathbf{2 0 1 2}$ & $175.302 .351,00$ & $123.981 .762,00$ & 51.320 .589 \\
\hline $\mathbf{2 0 1 3}$ & $150.975 .000,00$ & $85.216 .000,00$ & 65.759 .000 \\
\hline $\mathbf{2 0 1 4}$ & $324.365 .000,00$ & $88.875 .750,00$ & 235.489 .250 \\
\hline $\mathbf{2 0 1 5}$ & $96.000 .000,00$ & $111.957 .371,00$ & $(15.957 .371)$ \\
\hline $\mathbf{2 0 1 6}$ & $130.500 .000,00$ & $174.877 .932,00$ & $(44.337 .932)$ \\
\hline
\end{tabular}

Sumber Data : Badan Keuangan Daerah Kota Tomohon

Tabel di atas yang merupakan data penerimaan Pajak Hotel di Kota Tomohon selama periode Tahun Anggaran 2012-2016, yaitu data Target Penerimaan Pajak Hotel dan Realisasi Pajak Hotel.

\subsubsection{Analisis Efektivitas Penerimaan Pajak Hotel Kota Tomohon}

$$
\text { Efektifitas }=\frac{\text { Realisasi penerimaan pajak hotel }}{\text { Target penerimaan pajak hotel }} \times 100 \%
$$

1. Pada tahun 2012, target penerimaan Pajak Hotel sebesar Rp.175.302.351,00 dengan realisasi sebesar Rp. 123.981.762, 00, maka pehitungan efektivitas penerimaan Pajak Hotel tahun 2012 diperoleh hasil sebagai berikut :

$$
\begin{aligned}
\text { Tahun } 2012 & =\frac{123.981 .762,00}{175.302 .351,00} \times 100 \% \\
& =70,72 \%
\end{aligned}
$$

Jadi, tingkat efektivitas penerimaan Pajak hotel di Kota Tomohon pada tahun 2012 sebesar $70,72 \%$.

2. Pada tahun 2013, target penerimaan Pajak Hotel sebesar Rp. 150.975.000,00 dengan realisasi sebesar Rp. 85.216.000,00, maka perhitungang efektivitas penerimaan Pajak Hotel tahun 2013 diperoleh hasih sebagai berikut :

$$
\begin{aligned}
\text { Tahun } 2013 & =\frac{85.216 .000,00}{150.975 .000,00} \times 100 \% \\
& =56,44 \%
\end{aligned}
$$

Jadi, tingkat efektivitas penerimaan Pajak Hotel di Kota Tomohon pada tahun 2013 sebesar $56,44 \%$.

3. Pada tahun 2014, target penerimaan Pajak Hotel sebesar Rp. 324.365.000,00 dengan realisasi sebesar Rp. 88.875.750,00, maka perhitungan efektivitas penerimaan Pajak Hotel tahun 2014 diperoleh hasil sebagai berikut : 


$$
\begin{aligned}
\text { Tahun } 2014 & =\frac{88.875 .750,00}{324.365 .000,00} \times 100 \% \\
& =27,40 \%
\end{aligned}
$$

Jadi, tingkat efektivitas penerimaan Pajak Hotel di Kota Tomohon pada tahun 2014 sebesar $27,40 \%$.

4. Pada tahun 2015 target penerimaan Pajak Hotel sebesar Rp. 96.000.000,00 dengan realisasi sebesar Rp. 111.957.371,00, maka perhitungan efektivitas penerimaan Pajak Hotel tahun 2015 diperoleh hasil sebagai berikut :

$$
\begin{aligned}
\text { Tahun } 2015 & =\frac{111.957 .371,00}{96.000 .000,00} \times 100 \% \\
& =116,62 \%
\end{aligned}
$$

Jadi, tingkat efektivitas penerimaan Pajak Hotel di Kota Tomohon pada tahun 2015 sebesar $116,62 \%$.

5. Pada tahun 2016 target penerimaan Pajak Hotel sebesar Rp. 130.500.000,00 dengan realisasi sebesar Rp. 174.877.932,00, maka perhitungan efektivitas penerimaan Pajak Hotel tahun 2016 diperoleh hasil sebagai berikut :

$$
\begin{aligned}
\text { Tahun } 2016 & =\frac{174.877 .932,00}{130.500 .000,00} \times 100 \% \\
& =134,01 \%
\end{aligned}
$$

Jadi, tingkat efektivitas penerimaan Pajak Hotel di Kota Tomohon pada tahun 2016 sebesar 134,01\%. Dari hasil perhitungan persentase efektivitas Pajak Hotel dapat dilihat pada tabel 4.2 di bawah ini

Tabel 4.2

Hasil Analisis Efektivitas Penerimaan Pajak Hotel Terhadap Pendapatan Asli Daerah Kota Tomohon Tahun 2012 - 2016

\begin{tabular}{|c|c|c|c|c|}
\hline Tahun & Target (Rp) & Realisasi (Rp) & $\begin{array}{c}\text { Persentase } \\
\text { Efektivitas } \\
(\%)\end{array}$ & $\begin{array}{c}\text { Kategori } \\
\text { Efektivitas }\end{array}$ \\
\hline 2012 & $175.302 .351,00$ & $123.981 .762,00$ & $70,72 \%$ & Sangat Efektif \\
\hline 2013 & $150.975 .000,00$ & $85.216 .000,00$ & $56,44 \%$ & Sangat Efektif \\
\hline 2014 & $324.365 .000,00$ & $88.875 .750,00$ & $27,40 \%$ & Sedang \\
\hline 2015 & $96.000 .000,00$ & $111.957 .371,00$ & $116,62 \%$ & Sangat Efektif \\
\hline 2016 & $130.500 .000,00$ & $174.887 .932,00$ & $134,01 \%$ & Sangat Efektif \\
\hline
\end{tabular}

Persentase pada tahun anggaran 2012 sangat efektif, tahun 2013 juga masih Sangat efektif, namun pada tahun 2014 mengalami penurunan. Pada tahun 2015 juga naik sampai tahun 2016 masih sangat efektif. Realisasi penerimaan pajak hotel Kota Tomohon termasuk baik karna hampir 5 (lima) tahun terakhir sangat efektif walaupun pada tahun 2014 tidak mencapai target. Dengan persentase $134,01 \%$ merupakan tingkat efektivitas tertinggi selama kurun waktu 2012 - 2016. Untuk tahun 2012 realisasi pajak hotel masih mencapai target sebesar 70,72\% namun pada tahun 2013 realisasi pajak hotel masih mencapai target, walaupun mengalami penurunan sebesar 56,44\%. Pada tahun 2013 realisasi pajak hotel tidak mencapai target dan mengalami penurunan sebesar 27,40\%. Namun di tahun 2015 realisasi 
pajak hotel mengalami peningkatan yg sangat signifikan yaitu sebesar 116,62\%. Tahun 2016 merupakan tingkat efektivitas tertinggi selama kurun waktu 2012-2016.

Untuk tahun 2012 Realisasi pajak hotel masih mencapai target sebesar 70,72\% namun mengalami penurunan persentase di tahun 2013 sebesar 56,44\% artinya dari tahun 2012 sampai 2013 mengalami penurunan sebesar 14,28\%. Tahun 2014 realisasi pajak hotel mengalami penurunan sebesar $27,40 \%$ atau mengalami penurunan sebesar $29,04 \%$ dari tahun 2013. Di tahun 2015 realisasi pajak hotel kembali mencapai target sebesar 112,62\% artinya mengalami peningkatan yang sangat signifikan sebesar 89,22\% dari tahun 2014. Tahun 2016 merupakan realisasi pajak hotel tertinggi selama 5 (lima) tahun terkhir yaitu $134,01 \%$ atau mengalami peningkatan sebesar 17,39\% dari tahun 2015. Tingkat efektivitas di tahun 2012 sampai 2016 di katakana sangat efektif karna selalu mencapai target walaupun di tahun 2014 mengalami penurunan yang sangat drastis namun di tahun 2015 dan 2016 mengalami peningkatan realisasi pajak hotel yang sangat signifikan.

\subsubsection{Analisis Kontribusi Pajak Hotel Terhadap Pendapatan Asli Daerah Kota Tomohon.}

$$
\text { Kontribusi }=\frac{\text { Penerimaan pajak hotel }}{\text { Penerimaan pendapatan asli daerah }} \times 100 \%
$$

1. Pada tahun 2012, realisasi penerimaan pajak hotel sebesar Rp. 123.981.762,00 dengan realisasi Pendapatan Asli Daerah sebesar Rp. 11.242.635.125, maka perhitungan kontribusi Pajak Hotel tahun 2012 diperoleh hasil sebagai berikut :

$$
\begin{aligned}
\text { Tahun } 2012 & =\frac{123.981 .762,00}{11.241 .635 .125,00} \times 100 \% \\
& =1,10 \%
\end{aligned}
$$

Jadi, kontribusi Pajak Hotel terhadap Pendapatan Asli Daerah Kota Tomohon pada tahu 2012 sebesar $1,10 \%$.

2. Pada tahun 2013, realisasi penerimaan pajak hotel sebesar Rp. 85.216.000.000,00 dengan realisai Pendapatan Asli Daerah sebesar Rp. 13.945.339.275, maka perhitungan kontribusi Pajak Hotel tahun 2013 diperoleh hasil sebagai berikut :

$$
\begin{aligned}
\text { Tahun } 2013 & =\frac{85.216 .000,00}{13.945 .339 .275,00} \times 100 \% \\
& =6,11 \%
\end{aligned}
$$

Jadi, kontribusi Pajak Hotel terhadap Pendapatan Asli Daerah Kota Tomohon pada tahun 2013 sebesar $6,11 \%$.

3. Pada tahun 2014, realisasi penerimaan pajak hotel sebesar Rp. 88.875.750,00 dengan realisasi Pendapatan Asli Daerah sebesar Rp. 20.100.568.636, maka perhitungan kontribusi Pajak Hotel tahun 2014 diperoleh hasil sebagai berikut :

$$
\begin{aligned}
\text { Tahun } 2014 & =\frac{88.875 .750,00}{20.100 .568 .636,00} \times 100 \% \\
& =44,21 \%
\end{aligned}
$$

Jadi, kontribusi Pajak Hotel terhadap Pendapatan Asli Daerah Kota Tomohon pada tahun 2014 sebesar $44,21 \%$. 
4. Pada tahun 2015, realisasi pajak hotel sebesar Rp. 111.957.371,00 dengan realisasi Pendapatan Asli Daerah sebesar Rp. 24.657.382.659, maka perhitungan kontribusi Pajak Hotel tahun 2015 diperoleh hasil sebagai berikut :

$$
\begin{aligned}
\text { Tahun } 2015 & =\frac{111.957 .371,00}{24.100 .568 .636,00} \times 100 \% \\
& =\quad 4,65 \%
\end{aligned}
$$

Jadi, kontribusi Pajak Hotel terhadap Pendapatan Asli Daerah Kota Tomohon pada tahu 2015 sebesar $4,65 \%$.

5. Pada tahun 2016, realisasi pajak hotel sebesar Rp. 174.887.932,00 dengan realisasi Pendapatan Asli Daerah Rp. 26.011.141.966, maka perhitungan kontribusi Pajak Hotel tahun 2016 diperoleh hasil sebagai berikut :

$$
\begin{aligned}
\text { Tahun } 2016 & =\frac{174.887 .932,00}{26.011 .141 .966,00} \times 100 \% \\
& =67,23 \%
\end{aligned}
$$

Jadi, kontribusi Pajak Hotel terhadap Pendapatan Asli Daerah Kota Tomohon pada tahu 2016 sebesar $67,23 \%$.

Tabel 4.3

Hasil Analisis Kontribusi Penerimaan Pajak Hotel Terhadap Pendapatan Asli Daerah Kota Tomohon Tahun 2012-2016

\begin{tabular}{|c|c|c|c|c|}
\hline Tahun & $\begin{array}{c}\text { Realisasi } \\
\text { Penerimaan } \\
\text { Pajak Hotel } \\
(\mathbf{R p})\end{array}$ & $\begin{array}{c}\text { Realisasi } \\
\text { Pendapatan } \\
\text { Asli Daerah } \\
(\mathbf{R p})\end{array}$ & $\begin{array}{c}\text { Persentase } \\
\text { Kontribusi } \\
(\%)\end{array}$ & $\begin{array}{c}\text { Kriteria } \\
\text { Kontribusi }\end{array}$ \\
\hline 2012 & $123.981 .762,00$ & $11.241 .635 .125,00$ & $11,02 \%$ & Kurang \\
\hline 2013 & $85.216 .000 ., 00$ & $13.945 .339 .275,00$ & $6,11 \%$ & Sangat Kurang \\
\hline 2014 & $88.875 .750,00$ & $20.100 .568 .636,00$ & $44,21 \%$ & Baik \\
\hline 2015 & $111.957 .371,00$ & $24.657 .382 .659,00$ & $4,65 \%$ & Sangat Kurang \\
\hline 2016 & $174.877 .932,00$ & $26.011 .141 .966,00$ & $67,23 \%$ & Sangat Baik \\
\hline
\end{tabular}

Sumber Data : Hasil Pengelolaan Data 2017

\section{KESIMPULAN DAN SARAN}

\subsection{Kesimpulan}

Berdasarkan hasil analisis dan pembahasan yang dikemukakan pada bab sebelumnya, peneliti mengambil kesimpulan sebagai berikut:

1. Tingkat Efektivitas dari realisasi Pajak Hotel tahun 2012 -2016 bisa di katakana "Sangat Efektif" meskipun ada penurunan di tahun 2014. Karena di 2012, 2013, 2015, 2016 persentase tingkat efektivitas selalu melebihi angka di atas 50\% bahkan di tahun 2015 dan 2016 melebihi angka di atas 100\%. Tahun 2016 merupakan tingkat efektivitas pajak hotel tertinggi sebesar 134,01\%, sedangkan tingkat efektivitas pajak hotel terendah berada pada tahun 2014 dengan persentase sebesar 27,40\%

2. Kontribusi Pajak Hotel terhadap Pendapatan Asli Daerah (PAD) Kota Tomohon tahun 2012 - 2016 dari tahun ke tahun peningkatan dan penurunanya tidak stabil dengan kriteria kontribusi "Baik" walaupun ada penurunan yang signifikan di tahun 2012, 2014, 2015. Hal ini sangat mempengaruhi jumlah PAD yang diterima oleh pemerintah Kota Tomohon. Tahun 2016 merupakan kontribusi tertinggi Pajak Hotel 
terhadap PAD dengan persentase 67,23\% dan yang terendah berada di tahun 2013 dengan persentase sebesar $6,11 \%$ dengan rata - rata kontribusi sebesar $26.6 \%$.

\subsection{Saran}

Berdasarkan kesimpulan yang telah di kemukakan di atas, maka peneliti memberikan saran yang dapat di jadikan bahan pertimbangan dalam melakukan kebijakn yang berhubungan dengan efektivitas dan kontribusi pajak hotel terhadap PAD, yaitu :

1. Dilihat dari keseluruhan tingkat efektivitas pajak hotel pada tahun 2012-2016 sudah efektif meskipun terdapat penurunan di tahun 2014. Kebijakan yang harus di ambil oleh Pemerintah Kota Tomohon adalah mengatur atau mendata kembali hotel- hotel yang ada di Kota Tomohon dengan memberikan arahan atau sosialisasi kepada wajib pajak dalam melakukan pembayaran pajak atau pembayarannya menunggak khususnya di bidang Pajak hotel demi meningkatkan efektivitas pajak hotel terhadap Pendapatan Asli Daerah (PAD) Kota Tomohon.

Kontribusi pajak hotel terhadap Pendapatan Asli Daerah masih kurang sehingga pemerintah Kota Tomohon harus lebih memperhatikan dan mencari cara dalam meningkatkan kontribusi Pajak Hotel dengan cara menggali potensi-potensi yang ada di Kota Tomoho sendiri khususnya di bidan perhotelan, mencari jaringan yang mampu memajukan peningkatan pembangunan hotel yang ada di Kota Tomohon baik jaringan dari luar Kota Tomohon atau pun dari luar daerah Sulawesi Utara

\section{DAFTAR PUSTAKA}

Arikunto, Suharsimi. 2013. Prosedur Penelitian. Rineka Cipta, Jakarta.

Bilal Hasan. (2015). The Role of Value added Tax (VAT) in the Economic of Growth of Pakistan.

Djoko Muljono, Waruni Wicaksono. Akuntansi Pajak Lanjutan. Andi, Yogyakarta.

Diana Sari, 2013. Konsep Dasar Perpajakan. Bandung

Kementrian Keuangan RI Direktorat Jendral Pajak. 2013. Ketentuan Umum dan Tata Cara Perpajakan. E-book. Direktorat Jendral Penyuluhan Pelayanan dan Humas, Jakarta.

Kementrian Keuangan RI Direktorat Jendral Pajak. 2013. Lebih Dekat Dengan Pajak. Ebook. Direktorat Jendral Penyuluhan Pelayanan dan Humas, Jakarta.

Lubis, Irsan. 2015. Mahir Akuntansi Pajak Terapan. Berbasis Standar Akuntansi \& Ketentuan Pajak Terbaru. Andi. Yogyakarta.

Mardiasmo, 2016. Perpajakan Edisi Terbaru. Andi Yogyakarta.

Mahmudi, 2016. Analisis Laporan Keuangan Pemerintah Daerah. Buku Seri Membudayakan Akuntabilitas Publik. Edisi ke Tiga. Sekolah Tinggi Ilmu Manajemen YKPN. Yogyakarta.

Pontoh, Winston. 2013. Akuntansi Konsep dan Aplikasi. Halaman Moeka, Jakarta.

Pemerintah Republik Indonesia. 2009.Undang-Undang RI Nomor 28 Tahun 2009, tentang Pajak Daerah dan retribusi daerah. Jakarta.

Rudianto. 2012. Pengantar Akuntansi Konsep Dan Teknik Penyusunan Laporan Keuangan

Simamora, Henry. 2013.Akuntansi Manajemen, Salemba Empat, Jakarta.

Siahaan, Marihot P. 2013. Pajak Daerah dan Retribusi Daerah. Edisi Revisi cetakan 3. Rajawali Pers, Jakarta

Siahaan, Marihot P. 2013. Pajak Daerah dan Retribusi Daerah. Edisi Revisi cetakan 3. Rajawali Pers, Jakarta.

Siahaan, P. 2014. Utang Pajak, Pemenuhan Kewajiban, dan Penagihan Pajak dengan Surat Paksa. Fajar Interpratama Offset.Jakarta.

Simamora, Henry. 2013. Akuntansi Manajemen, Salemba Empat, Jakarta. 
Suwardjono,2013. Akuntansi Pengantar Bagian. Edisi Pertama. Grah Ilmu. Yogyakarta.

Sari, Diana. 2013. Konsep DasarPerpajakan. Cetakan Kesatu. Refika Aditama. Bandung. Sujaweni, V. Wiratna. 2014. Metodologi Penelitian. Pustaka Baru Press. Yogyakarta.

Sugiyono, 2016. Metode Penelitian Kuantitatif, Kualitatif, dan R\&D. Alfabeta. Bandung.

TMBooks. 2015. Cermat Menguasai Selut - Belut Perpajakan Indonesia. Andi Yogyakarta.

TMbooks.2013.Perpajakan Esensi dan Aplikasi. Andi Yogyakarta

Thomas Sumarsan, 2015. Perpajakan Indonesia edisi 4. Yogyakarta.

Umeora C. Emmanuel., (2013). The Effects of Value Added Tax (V.A.T) on the Economic Growth of Nigeria. Vol. 4, No. 6, 2013. Anambra State University. 